\title{
Strengthening Halal Tourism Based on Prophetic Islamic Law through The Historical Social Inference of the Sasak, Samawa and Mbojo
}

\author{
${ }^{1}$ Nurjannah S, ${ }^{2}$ Rina Rohayu H, ${ }^{3}$ Khudzaifah Dimyati, ${ }^{4}$ Absori \\ 1,2Universitas Muhammadiyah Mataram, Mataram, Indonesia \\ 3,4Universitas Muhammadiyah Surakarta, Surakarta, Indonesia \\ 1․ㅡurjannah@gmail.com, ${ }^{2}$ rinarohayu@gmail.com, ${ }^{3}$ khudzaifah@gmail.com, ${ }^{4}$ absori@gmail.com
}

\begin{tabular}{|c|c|}
\hline Article Info & Abstract \\
\hline $\begin{array}{l}\text { Article History } \\
\text { Received: July 12, } 2018 \\
\text { Accepted: September 30, } \\
2018\end{array}$ & \multirow{2}{*}{$\begin{array}{l}\text { The legal paradigm of halal tourism which is being built by the government } \\
\text { West Nusa Tenggara Province is based on oriental characters, civilization, } \\
\text { and culture with the main scheme to attract the world Muslim tourists. The } \\
\text { development of legal paradigm of character-and-civilized-based tourism is } \\
\text { important in order to establish local identity of a particular area, which is } \\
\text { now declining. This paper aimed to discus legal concept of halal tourism } \\
\text { based on Islamic prophetic through social historical inference of Sasak, } \\
\text { Samawa, and Mbojo ethnic groups. This research used legal analysis method } \\
\text { of sociological jurisprudence and prophetic legal method with integrated- } \\
\text { interconnected approach through the procedure of social historical } \\
\text { interference. The finding revealed there is a convergence of Islamic prophetic } \\
\text { values and social historical values of Sasak, Samawa, and Mbojo reflected in } \\
\text { the patterns of halal food, social relation, clothes, economy, and the like. } \\
\text { Common philosophy of Sasak, Samawa, and Mbojo, that is "adat bersendi } \\
\text { syara', syara' bersendi kitabullah" (tradition is based upon sharia, sharia is } \\
\text { based upon the Book of Allah) supports the Islamic identity that has provided } \\
\text { a foundation for the issuance of halal regulation and the accommodation of } \\
\text { character and civilized based local identities through local friendly entities. }\end{array}$} \\
\hline $\begin{array}{l}\text { Keywords } \\
\text { Halal Tourism } \\
\text { Prophetic Islamic Law } \\
\text { Historical Social Inference }\end{array}$ & \\
\hline $\begin{array}{l}\text { Support by: } \\
\text { dol Crossref }\end{array}$ & \\
\hline
\end{tabular}

\section{INTRODUCTION}

Indonesia is one of the countries with the largest Muslim population in the world, and it becomes one of the reasons in strengthening the commitment of halal tourism development, in order to be equivalent to other countries that have been more advanced in the development of halal tourism. Ministry of Tourism data in 2013 has set 13 (thirteen) provinces to become the leader of Halal tourist destination, namely West Nusa Tenggara (NTB), Nangroe Aceh Darussalam, West Sumatera, Riau, Lampung, Banten, DKI Jakarta, West Java, Central Java , Yogyakarta, East Java, South Sulawesi, and Bali.

Based on the latest data released by Thomson Routhers, in 2006, Indonesia is not included in the top ten ranks of halal tourism destination, whereas in 2015 based on data released by the Global Muslim travel index (GMTI), Indonesia comes into the group of destination countries organization of Islamic cooperation (OIC), and is ranked sixth as a halal tourist destination after Qatar, Saudi Arabia, UAE / UAE, Turkey and Malaysia, and the seventh position according to UNWTO's report on Thomson Routhers and the Standard Dinar released in 2014.

The development of halal tourism in West Nusa Tenggara becomes a necessity, in support of programs from the central government, as a manifestation of the commitment of local governments in the context of economic development and tourism 
in the region. Halal tourism, with the main scheme is the world's Muslim tourists, is required to provide a concept and service that qualified and in accordance with the characteristics of its users through the slogan of Muslim Friendly Tourism. Therefore, the normative and empirical aspects become very important in order to integrate halal tourism at the level of concept until its implementation.

The issuance of Regional Regulation number 2 of 2016 on Halal Tourism, gives local government commitment to its readiness and seriousness in strengthening branding of halal tourism in West Nusa Tenggara. So far, local regulations (perda) on West Nusa Tenggara halal tourism is the only regulation in Indonesia and other regions do not have it, so every aspect is expected to be able to be done and prepared either macro or micro.

The scope of halal tourism, as embodied in Regional Regulation No. 2 of 2016, covers destinations, marketing and promotion, institutional industries, coaching, supervision and financing. Managers of halal tourism destinations, must build and provide public facilities that support the convenience of halal tourism activities, such as places and equipment of Muslim tourists worship, washing facilities that meet the standards of syar'i, halal food both from raw materials, processing, as well as their cooking utensils, clothing and civilized patterns that conform to Shariah standards and the customs and culture of the people of West Nusa Tenggara.

Reflecting with other areas that develop sharia tourism, then West Nusa Tenggara Halal Tourism was expected to have the identity and characteristics that show the correlation of the concept of halal and sharia concept. When viewing data from the Ministry of Tourism and Creative Economy of Indonesia, the target of the development of sharia tourism by the minister of tourism and creative economy of Indonesia, are Aceh, West Sumatra, Riau, Lampung, Banten, Jakarta, West Java, East Java, Makasar and Yogyakarta where the target areas of development of Islamic tourism that has a great opportunity .

West Nusa Tenggara has not yet entered in the areas of priority development of Islamic tourism, based on the data mentioned above, so it is necessary to clarify scientifically about it. It aims to show the world, both nationally and internationally, that West Nusa Tenggara is very likely to do so. This is evidenced by the award at the World Halal Tourism Awards (WHTA) event in Abu Dhabi on Wednesday, December 7, 2016, from the three categories that followed. Lombok in particular West Nusa Tenggara won the title. Sembalun Village re-selected as the best Halal honeymoon destination ( World Best Halal Honeymoon Destination) 2016, Novotel Lombok resort \& villas as the best seaside beach resort (World Best Halal Beach Resort), and site www.wonderfullomboksumbawa.com as the best halal tourism site world (World's Best Halal Travel Website) .

Spirit of World Halal Tourism Awards champion becomes an important and sustainable note, so it still requires proper formulation and proper integration between the concept of halal tourism with the values of customs and socio-cultural community, with one such attempt Lombok will be used as eco-halal tourism model, through activation of halal tourism movements and branding industries.

On this basis, this research becomes a solution in finding the formulation of West Nusa Tenggara Halal tourism concept which is correlated with the customs and culture of tribes that inhabit the islands of Lombok and Sumbawa island, namely Sasak, Samawa and Mbojo (Suku Sasambo). The concept of halal tourism will also be the main base in the formulation of other Shari'ah regulations, as well as the operational standards of halal tourism procedures, following the presence of the community in the form of local friendly entities and civilized (Local Friendly Entities). 


\section{METHOD}

The method used in this research is social jurisprudence law reasoning method. The method of social jurisprudence law reasoning is used in order to bridge the legal positivism and legal historism which is the object of ontology. As the opinion of Eugen Erlich who is a pioneer of social schools of jurisprudence said that, "a new positive law will be effectively determined and assessed from the point of view of assimilation (conformity) with the law that lives in society". On the other hand, this suitability can be found in the presence of convergence or common ground of legal values that live in society with certain religious values that guide the life of a society in a textual and contextual way. Therefore, in order to strengthen the method of social jurisprudence in the analysis of this study, researchers also use the method of interconnectionintegration in the prophetic paradigm, as a basis in analyzing the socio-historical inferences of the sasak, samawa and Mbojo tribes associated with customary values born and awakened in order to become the basis of strengthening of halal tourism law in West Nusa Tenggara in the future.

\section{RESULT}

\section{The Concept of Islamic Prophetics Law and the Relation with Tourism}

Prophetic law basically come from the legal reform paradigm in Indonesia. The prophetic paradigm is known as the law that comes from the "revelation" of God. The prophetic paradigm in legal science is made as a reconstruction process. The reconstruction in question is in the overview of the prophetic social sciences, as the concept which involves the creator in determining the norms built by man.

Springhead of the prophetic law paradigm, which is contained in a legal product, one of which is the achievement of interobjective justice (ummatan wahidah). Kuntowijoyo provides a view of legal justice that the pattern of adopting legal diversity, and each community group based on its values can build normative formulations and can be judged on the basis of their respective laws. This means legal pluralism that trigger the legal tolerance, because each party already has its own norms that also should not be blocked its application. The assumption that the sense of justice in Pancasila is pluralist so that at the same time the sense of justice also varies according to the stratification and legal development of each religious people.

The concept of the prophetic paradigm, in the relation among men, nature and God, there are four relations, namely: ontological relationships, communicative relationships, status relations (master-servants), and ethical relations hard cross gratitude and fear). These relationships carry the consequences of an integral ontological structure, the nature of creation, the principle of human equality and the universe obeying natural laws, mandates, and certain ethical visions. Thus, there are four things that must be had in the mind of the legal subject, which are about the concept of the best people, historical activism, transcendence and liberation.

The historical inference method of textual and social inference used in this study is used in order to analyze how the texts (revelations) derived from the Qur'an and Sunnah are interpreted and accepted by indigenous peoples who are embrace Islam religion. The current interpretation of contemporary tourism concepts are tried to relate to how the concept of Islam and how indigenous peoples who embrace Islamic values integrate it in everyday life, and have a positive impact on the legal order in society. 
Infiltration of Islamic religious teachings in the legislation can use the prophetic law paradigm in the formation stage until law enforcement. This interconnectionintegration theory has been triggered and built on the basis of Islamization of Islamic science and science integrate to islamic text. Islamization of science composed of elements of monotheism, moving from context to text, and Islamic scholarship consisting of Islamic / prophetic demystification, moving from text to context. Contextuality intersects with the traditions (customs) of society, so that an inference procedure is needed in the process of integration-its interconnection departs from the socio-historical society.

Tradition which is also referred to as custom. Customs and Islam are seen as two parts that are inseparable from one another. There is tradition integrates to islam and islam integrates to tradition. This makes Islam as a universal religion, in which there are values that can be well received by all people, both Muslims and non-Muslims. There is a concept of Islam in the context of tourism, namely"ziyarah" which have the meaning visiting. As a consequence of the tradition of "ziyarah", there were also various forms of Islamic social institutions originating from their ethical and normative values. In the end, the concept of "dhiyah" appeared, which is the conduct of visits which regulated ethics and manners in social relations between guests (dhaif) with the host (mudhif). The concept and tradition of ziyarah, then experience development in various forms between one region and another.

The term "halal tourism" was first socialized to the public at the 2000 in Organization of Islamic (OIC) meeting. "Halal tourism" is one of a way to the many requests from tourists Muslims who want tourism that accommodates the Muslim lifestyle. The form of accommodation is the concept of "halal tourism" such as sharia tourism, Islamic tourism, halal travel, halal lifestyle, Muslim friendly destination travel, halal friendly tourism destinations, and Muslim friendly tourism and other terms developed by various countries in accordance with the desired characteristics. Contemporary Arabic is also known as the term al-siyahah for the concept of tourism or tourism. The Qur'an mentions the word al-siyahah, in several places (Q.-Taubah: 2 and 112).

Islamic law regulates the criteria for food or animals that are forbidden for consumption. First, illigitimate lidzatihi, which is illigitimate because of the subtances. The point is that the law of origin from the food itself is indeed forbidden. Based on the words of Allah Azzawajalla in the Qur'an and the Words of the Prophet Muhammad Sallallahu'alaihi wasallam, in his hadiths, it can be known that certain types of food are forbidden for human consumption because the essence of the food itself has been forbidden by Allah and The prophet, such as blood, pork, khamar (liquor), all wild beasts, with their fangs preying on and attacking their prey, all types of clawed birds, with their claws gripping or attacking their prey, all animals ordered to be killed, all fierce beasts, all animals that are forbidden to be killed, tame donkeys (not wild ones ), animals born from the marriage of two different types of animals, one of which is halal and the other is haram, dog, bad or disgusting animal, all foods that are harmful to human health. Second, Haram Lighairihi, (food that is forbidden due to external factors). That is to say the law from which food is halal, but it turns out to be illigitimate because of food source. For example, food from the result of stealing or buying money from corruption, usury transactions, wages of prostitution, shamanic offerings, and so on. In this case the food and drink are unlawful such as animals slaughtered for offerings, animals slaughtered without reciting basmalah, carcasses (except fish and grasshoppers), fetus which is in the stomach of an animal slaughtered, food obtained by 
illegitimate means, Jallalah (animals that are mostly food is human faeces / feces or other animal feces or are unclean).

In the context of dress regulation according to the Islamic prophetic paradigm, is that clothing is one of the greatest favors of Allah Azzawajallah given to humans. The function of clothing is a tool to cover genitals, hold the body from hot and cold conditions and as a deterrent to damage caused by other causes.

Some cultures in dressing according to the Islamic law, consisting of, 1) must cover genitalia; 2) should be thick and not transparent so that the appearance of genitalia and skin color and curves, and the behavior of both male and female clothing; 3) does not resemble women's clothing for men nor does it resemble men's clothing for women; 4) Menbal is not allowed (more than ankles). And this prohibition includes clothing in the form of robes, sarongs, pants and robes; 5) illigitimate wearing clothes with images of crosses or pictures of living creatures; 6) illigitimate wearing shuhrah (popularity) clothes; etc.

\section{Normative Research of Halal Tourism in West Nusa Tenggara}

Halal tourism requires conceptual and contextual indicators. In the conceptual domain, it can be found that this indicator of halal tourism can be seen from the existence of positive legal norms accommodated in other laws and implementing regulations, such as article 18 paragraph (6) of the 1945 Constitution of the Republic of Indonesia; Law Number 10 of 2009 concerning tourism; Law Number 23 of 2014 concerning Regional Government; Government Regulation Number 50 of 2011 concerning the Master Plan for National Tourism Development; Minister of Tourism and Creative Economy Regulation number 2 of 2014 concerning Guidelines for Implementing Sharia Hotel Businesses; Regional Regulation Number 7 of 2013 concerning the Master Plan for Regional Tourism Development, and the regulation of West Nusa Tenggara No. 2 year 2016 about halal tourism ; National Sharia Council Fatwa Indonesian Ulema Council (DSN-MUI) concerning the management of halal tourism industry. In addition, the concept of halal is agreed as a concept that accommodates a religious norm that is recognized that, the norm above is the main reference in every aspect of tourism that exists. The issuance of the National Sharia Council Fatwa Indonesian Dominie Council (DSN-MUI) concerning the management of halal tourism industry, due to the absence of rules regarding the development of halal tourism in Indonesia after the revocation of the Minister of Tourism and Creative Economy regulation number 2 of 2004 concerning guidelines for the implementation of sharia hotel business. Thus, regulations governing halal tourism need to be made, so that the implementation can refer to a clear regulation / regulation.

The definition of halal tourism based on Article 1 letter 16 of Regional Regulation No. 2 of 2016, is a tourist visit with a tourism destination and industry that prepares product facilities, services and tourism management that meets sharia. Furthermore the halal tourism industry includes accommodation, travel agents, restaurants and spas. The management of the halal tourism industry is always guided by the DSN-MUI provisions concerning the management of the halal tourism industry.

Accommodation in accordance with sharia standards in the regional regulation must fulfill several conditions: a) availability of facilities that are suitable for purification; b) availability of facilities that make us easy to worship; c) availability of legal food and drink, d) safe and comfortable facilities and atmosphere for families and businesses; and e) maintaining sanitation and environmental hygiene.

In the provisions of article 15 paragraph 2 of regional regulation number 2 of 2016 concerning halal tourism, said "halal certified food and beverage providers must guarantee the halal of food / drinks served, starting from the supply of raw materials to 
the presentation process as evidenced by halal certificates". Furthermore, in the provisions of article 17 regulates that "Every spa businessman, sauna and halal massage parlor is obliged to use official halal logo products" so that every businessman who provides such services must provide: a) separate treatment rooms for men and women; b) mind therapy and physical therapy do not lead to sharia violations; c) male therapists specifically for men and women therapists specifically for women; and d) facilities that make it easy to pray.

Furthermore, in article 19 of regional regulation number 2 of 2016 concerning halal tourism, also regulates the requirements of someone to become a tour guide, namely: a) understanding and being able to carry out sharia values in carrying out duties; b) good character, communicative, friendly, honest and responsible; c) look polite in accordance with Islamic values and ethics; and d) provide Islamic values during the tour.

The normative aspect of West Nusa Tenggara halal tourism as described above, has sufficiently accommodated aspects of service, licensing, and infrastructure facilities that must be owned and provided by service providers and businesses in halal tourism. However, there are some things that have not been accommodated in this regard, such as the hospitality service standards that hotels only provide accommodation for couples who are lawful in the laws of religion and state law by showing a family card or marriage book. This is very important, considering that this provision will be one of the standards of comfort and protection for halal tourists, especially Muslim tourists and their families.

\section{Islamic Profetic Convergence and Traditional Custom Value of Sasak, Samawa and Mbojo as Foundation of Halal Tourism Strengthening}

Convergence is a terminology about the meeting point of an object which is reseaerched. This new point becomes a pattern that tries to be interpreted as a possibility that will give birth to equations or homogenity. The meeting point between the Islamic prophetic concept and the tribal values that exist and form within the Sasak, Samawa and Mbojo indigenous peoples (Sasambo Tribe), is related to aspects of halal food, clothing and civilized patterns of association, as well as economic aspects. The new point is expected to be a conceptual and contextual formulation in order to strengthen the legal identity and norms of halal tourism in West Nusa Tenggara.

Finding this convergence requires several procedures. One of them is through textual inference procedures found in Islamic treatises that are used and become references for these tribes in daily life, especially with regard to halal food, clothing and social patterns and economic concepts. Furthermore, in the context of socio-historical inference, it will be seen how the context of textual inference is accommodated and implemented in the indigenous people of Sasak, Samawa and Mbojo.

The Islamic prophetic paradigm which is seen in some character actions that occur in some forms of perceptions, views and patterns of behavior of the sasak, samawa and mbojo tribal peoples. In this case, globally and universally, it is seen that the philosophy of these three tribes (Sasambo tribe), is the traditional philosophy based on islamic law, an islamic law based on the book of ALLAH SWT. This philosophy is used as the main embryo in assessing and justifying that customs in West Nusa Tenggara in the three major tribes that inhabit it has a strong correlation with Islamic teachings and values. So that it will be a reference indicator in regulating, binding and even forcing people to obey the existing legal norms.

In the social context, the philosophy of " custom based on islamic law, and islamic law based on the book of ALLAH SWT ", gives recognition that Islamic law is the main foundation of existing tribal customs. This has a relationship with one of the concepts of Islam, namely Al Aadatu Muhakkamah which means that tradition is valid as a 
regulation or law. Customs in this concept are customs that do not contradict with Islamic law.

In the Sasak tribe, Islam was born and strong and cannot be separated from the role of the ulama, one of them is the theologians in East Lombok and some call them as Islamic Sasak elite in Lombok. This is because the East Lombok clerics have succeeded in holding strategic positions in the administration of the West Nusa Tenggara region.

The Islamic Sasak elite in Lombok carried out a strategy in constructing their identity. The construction of identity and legitimacy is built through educational channels (formal and non-formal, political and ceremonial. But in the long journey of Islam in Lombok, starting from how early the arrival of Islam, the development of Islam during the Islamic kingdom of Islam development in the center of Islamic cities, until the political changes that affected the development of Islam until the emergence of master teacher in the 18th century and 19, "not found" in various sources. This rise several understandings of the history of Sasak Islam which are beheaded. However, this can be minimized by serious efforts to reconstruct the historical journey of Sasak Islam using a historical approach. The coming of islamic power from the east which coincided with the efforts to improve Islamic teachings in Lombok, brought big impact on the development of Islam later. The influence of the Islamic empire from the east directly to the palace of the cities and travelers has made an appearance of Islam more clearly among the people of Sasak. From here, there are many figures who intensely preach Islam even to the level of purification of Islamic teachings.

The socio-cultural side of the Lombok community seen in the sasak community until the most memorable is that in the community arrangement in the form of mutual cooperation both in making houses, working on rice fields, death and so on. They always help other people and do everything together. After an age shift little by little, their lifestyle changes. However, community solidarity is reflected in several forms of value socialization, forms of interaction and censuses or collective agreements. This can be seen in belangar activities which means synonymous with the term mourn, mourn carried out not only to visit and entertain families who were hit by calamities, but also by giving participation in material form, the cost of completing the corpse, carrying the needed items such as rice, coconut, sugar and so on.

Betulong, is a form of sasak tribal community solidarity in the form of helping someone complete a job without expecting rewards, but based solely on sincerity that arises from their conscience. The form can be in the form of material and can be in the form of labor in helping to finish building a house, working in the fields, preparing food for certain events. The food served by the traditional Sasak community consists of ares vegetables (banana leaf), bebalung (beef), urap (vegetables), fish satay, and others. Banjar, is a social institution that aims to help each other to solve urgent problems and cannot solve itself such as marriage, circumcision. Betangko, attend a salvation or celebration event. Bejango, a form of social solidarity among the sasak people in the form of visiting sick people. Ngayo, is visiting the household by visiting without being invited first in order to build a closer family relationship.

In the Samawa tribe, the Islamic philosophy is strengthened from the results of previous studies that the Samawa tribal customs are very thick in the nuances of the culture of the original community, in line with the adopted religion of Islam. Philosophy "custom based on islamic law and islamic law based on the book of ALLAH", which means that all individual behavior must be in accordance with customs, and all refer to the guidance of the Qur'an and Hadith. People who miss and get out of the guidance of customs are called "Tau No To 'basa", those people who do not know the rules at all. There are several examples of cases in the field of tourism, for example there was 
coverage in Sumbawa by a private television station, which featured Sumbawa culinary tours with dishes made from animal raw materials which were not commonly eaten in the Sumbawa region, namely the frog (lepang) with the food name "siong sira frog "and" gecko coffee powder "drink. National TV shows adventure session about Sumbawa culture which was arranged by Sumbawa's special food and drinks reaped protests. This is because, in the show, food and beverages mixed with powder from animals were not commonly consumed by the Sumbawa people. The program also became viral on social media, because it was disputed and questioned by the Sumbawa people. "There is no illigitimate food or drink in Sumbawa. We don't eat food or drinks which are forbidden by religion. "Our tradition is based on islamic law, islamic law is based on the book of Allah", said Adrian Pranata Ilham, Head of Tourism Promotion for Youth and Sports and Tourism (Disporapar) of Sumbawa Regency. This raises pros and cons in the community, especially among Sumbawa people.

Tradition is based on islamic law, islamic law is based on the book of Allah, in the Sumbawa community means adat based on the Shari'a, Shari'a based on the book of Allah. This can be seen in the teachings of previous people "palajar pasatotang tau loka samawa" which is "takit ko Nenek, kangila boat lenge", meaning fear of Allah, shame of doing bad things.

In the concept of halal food, there is the term Pasaji. Pasaji is food prepared through a process that is in accordance with halal both from the ingredients and the process. Sumbawa people believe that, whatever goes into a person's mouth and stomach, it will influence his attitude and behavior. So that if there is a deviant behavior, then there is a sentence: "how come it's not" means what the vegetables are, so they can do that. On the pattern of social interaction of the people of Samawa, always upholds the spirit of Basiru (helping each other) or love each other, mutual-kindness, visiting each other, mutual sharing, remind each other of goodness, protect each other,, mutual-love, mutual-trust, mutual respect, Mutual assistance.

Furthermore, the clothes used by the indigenous people of Samawa are known as "batedung tuntang", which is the veil of Syar'i covering headby using a woven sarong typical of "sesek fabric". In the aspect of customary institutions and customary norms that exist in the samawa tribe in the form of a Rappang and in the form of "Buk" (ancient manuscripts), there is an explanation of how the pre-empire transition to the Islamic era that Riba developed before among the authorities was forbidden by Islam and emphasized the king to run the economy based on Islamic principles, as well as other aspects of life.

In the Mbojo tribe, the history of the entry of Islam was inseparable from the historical betrayal process carried out by a figure named Salisi, he dared to violate the customs that had been made through his ancestral vows for his personal ambitions and did not hesitate to kill the royal figures who were regarded as obstacles. But through a bitter and bloody struggle and sacrificing everything that was done by one of the young leaders at that time, La Ka'I against the Salisi terror, then with La Mbila with popular support and Makassar assistance, he succeeded in defeating Salisi. On the 10th of Rabi'ul Awal, 1018 H. (1609 AD), four Mbojo nobles or Bima kingdom agreed to accept the teachings of Islam brought by traders from Gowa who first converted to Islam and changed their names to Islamic names, namely La Ka'I (Abdul kahir), La Mbila (Jalaluddin), Bumi Jara Mbojo (Awaluddin) and manure Bata (Syriajuddin).

The existence of Islam, and the application of prophetic Islamic values to the Mbojo tribe, are strongly influenced by its historical social factors. Historically, Islam entered the land of Bima with the first occurrence of conflict in the kingdom of Bima, and the assistance of cooperation from other kingdoms, the Gowa kingdom in solving its 
internal problems. As a result of this, it influenced the concepts and beliefs of the Mbojo nobles who were formerly Hindus and Buddhists, then accepted peacefully and confidently the Islamic values that came and were brought by the people of Gowa.

In $1633 \mathrm{AD}$, La Ka'I was crowned as Sultan of Bima I by the name of Sultan Abdul Kahir. On July 6, 1640, it had become an important event which was the momentum for the development of politics, religion and socio-culture among the Mbojo (Bima) community in the future.Since that time, the royal system ended, replaced by a new government system called the sultanate, a system of government based on Islam and a cultural system (adat) that was guided by Islamic religious norms (,, urf shahih).

From that moment on, Islam officially became a state religion, replacing the position of cultural religion with the change of religion of religion (ma kakamba ma kakimbi) who had mingled with Hinduism and Buddhism. Along with changes in the religion of the community, there is also a change in culture (adat). A previously un-Islamic (,, urf fasid) cultural system was replaced with Islamic customs (, urf shahih). Customary change as an abstract form of culture greatly influences the form of concrete culture, namely the social system and physical culture (material). Starting from that time the development of social systems and physical culture must be guided by the norms of Islamic religion, in other words the culture of Mbojo Islam, especially in terms of its substance.

Furthermore, the mbojo custom is expected to be a good custom by and for the people, so that the ruler in this case the bima sultanate together with the ulama are accommodated in a government institution called Syara ' Law. Syara ' is The law formulates a new idea based on Islam which is taken from the essence of the value of faith and piety in order to enrich the treasures contained in Dana Mbojo custom. The new idea was given the name "Maja Labo Dahu" (shame and fear). "Maja Labo Dahu", contains instructions to all levels of society who have pledged the sentence of monotheism to practice the values of faith and daily devotion in 'ubudiah (worship) and mu'amalah (benefaction).

The concept of halal food for the Mbojo tribal people can be seen from the raw material of the type of food commonly consumed by the people, which is usually served at traditional occasions, namely gule meat, satay, pickles whose raw materials are from goat meat and beef, palumara (ingredients raw from sea fish or freshwater fish, urap and saroncoo hi'i. Judging from the food served, it comes from ingredients that are ligitimate in islamic law.

In the association pattern of the Mbojo indigenous people, it is known for its strong patterns of upholding deliberation and the spirit of kaboju karawi (mutual cooperation). When meeting and interacting with other people, the language that is always used is "kalembo ade" which means to be patient, sincerity of conscience. This was spelled out in order to give appreciation and sympathy to the interlocutor. Although on the other hand the saying "kalembo ade" has various meanings and meanings according to the situation and conditions experienced. In addition, the term and philosophy of Maja Labo dahu is also known, meaning that any rules based on culture or human works cannot be separated from God's rules. Maja means shame, shame to do something that violates God's rules, and Dahu means fear. Fear of committing crimes and ugliness.

\section{CONCLUTION}

The Sasak, Samawa and Mbojo tribes (Sasambo Tribe), have historically been socially similar. This is due to the same belief as Muslim indigenous peoples. In terms of food, clothing and special social patterns, the Sasambo tribe shows similarities, for example from the type of food commonly consumed, derived from animal meat that is lawful in 
Islamic law, such as cattle, goats, buffaloes, horses, fish, and so on. In clothing, the Sasambo are known as rimpu, batedung tuntang. And in the pattern of association, also known patterns of solidarity and cooperation help in various activities such as marriage, circumcision, death, and so on. Although on some issues there are divergences or dividing points between traditional values and Islamic values, it becomes a process of legal pluralism that is present and emerging, along with the development of modernism. Therefore, the actualization of converged traditional values and Islamic values is expected to be maintained in the framework of strengthening the legal system, through the correlation of the prophetic paradigm and the traditional paradigm. This condition is fundamental to halal tourism in West Nusa Tenggara, in order to establish law and build a local paradigm that is friendly and civilized through local friendly entities.

\section{REFERENCE}

[1] A.A.Ngr Anom Kumbara, the construction of sasak people identity in East Lombok, Humaniora Journal, volume 20, Nomor 3, Oktober 2008.

[2] Abdullah Ahmad in Muhammad Mutawali, the implementation of islamic law in the king of bima, Preprints, Created On: Oktober 29, 2017, Last Edited: July 02, 2018.

[3] Absori Dkk, Critical Prophetic Law Against the Non-Systematic Law Paradigm, Genta Publishing, Mold I, September Yogyakarta, 2015.

[4] Ade Ela Pratiwi, haria Tourism Market Analysis in Yogyakarta City, Media Wisata Journal, Volume 14 Number 1, May 2016.

[5] Aries Zulkarnain, Leadership in Customs and Rappang Tanah Samawa, Publisher Ombak, Cetakan 1, Yogyakarta, 2011.

[6] Fahadil Amin Al Hasan, Organizing Halal Tourism in Indonesia (DSN-MUI Fatwa Analysis on Guidelines for Organizing Tourism based on Sharia Principles), AlAhkam Journal, Volume 2, Number 1, January 2017.

[7] Hashim Bin Muhammad Bin Husain Naqur, Al-Ahkam Al-Siyahahwa Atsaruha: Dirasah Syar'iyyah Muqaramah (Riyadh: Dar Ibn Al-Jawzi, 1424).

[8] Results of Interview with Adrian Pranata ilham, Sumbawa, Indigenous Syara, Syara Bersendikan Kitabullah, Head of Tourism Promotion of the Sports and Tourism Agency (Disporpar) of Sumbawa Regency, was also published in kabarsumbawa.com, November 2017.

[9] Hilir Ismail, Maja Labo Dahu as the Philosophy of Living in the Present Context, Paper at the National Day and Performing Arts Seminar, Bima 2001.

[10] Jamaluddin, Sasak Islam: History of Religious Social in Lombok (XVI-XIX century), Indo-Islamika, Volume 11, Number 1, 2011/1432.

[11] Nurjannah S, Islam and the State: Study of Accommodation in Islamic Law in Banking and its Application Problems in Indonesia, Proposal for Dissertation of Students of the Doctoral Program in Postgraduate University of Muhammadiyah Surakarta, on the seminar and tested on January 21, 2017.

[12] Novi Rizki Aulia, Social and Cultural Food of the Family of the Mbojo Tribe in Mataram City, Student Paper of the Ministry of Health of the Ministry of Health Mataram, Tuesday 16 June 2015, novrizkiaulia1011.blogspot.com, accessed on Tuesday, 10 April 2018.

[13] Rizkia Amelia Sania Putri, Critical Review of the Establishment of Regional Regulations Based on Customary Law and Islam as Actualization of the Values of Indonesian People, Legal Stage, Journal of the Indonesian Law Student Association Branch of Yogyakarta Special Region, Volume 1, Number 2, June 2015.

[14] Rizkia Amelia Sania Putri, Critical Review of the Establishment of Regional Regulations Based on Customary Law and Islam as Actualization of the Values of 
Indonesian People, Legal Stage, Journal of the Indonesian Law Student Association Branch of Yogyakarta Special Region, Volume 1, Number 2, June 2015.

[15] Shaykh Amin bin Abdullah al-Syaqawi, Adab Dressed, translated by Abu Umamah Arif Hidayatullah, Islamhousecom, 2014.

[16] Sainun, Interaction of Islamic Value and Customary Values: Traditional Ceremony Study of the Sasak Lombok Tribe Society, West Nusa Tenggara, Sunan Ampel UIN Surabaya, Digilib.uinsby.ac.id, 2015.

[17] Suarantb.com, Lombok Reaches Three Champions in "World Halal Tourism Awards" 2016, Published on December 8, 2016.

[18] State of the Global Islamic Economy 2014-2015 Report. Developed and Produced by: Thomson Routhers in Collaboration with: Standard Dinar.

[19] Toshihiko Izutsu, Relationship between God and Humans: A Semantic Approach to the Koran, Happened Agus Fahri Husein, Supriyanto Abdullah and Amirudin, (Yogyakarta: PT. Tiara Wacana), 2003.

[20] Ustadz Muhammad Wasitho Abu Fawas, Halal and Haram Food Criteria, Muslim Entrepreneur Magazine 15-16 Edition, Volume 2 Year 2011 M. 